\title{
False increase of serum cancer risk markers in a case of benign uterine bleeding
}

\section{Argiri Sianou, George Galyfos*, Dimitra Moragianni, Stiliani Demeridou, Georgios Kaparos, Evaggelia Kouskouni}

Department of Microbiology, University of Athens Medical School, Areteion Hospital, Athens, Greece

Received: 08 May 2016

Accepted: 02 June 2016

\section{*Correspondence:}

Dr. George Galyfos,

E-mail: georgegalyfos@hotmail.com

Copyright: $\odot$ the author(s), publisher and licensee Medip Academy. This is an open-access article distributed under the terms of the Creative Commons Attribution Non-Commercial License, which permits unrestricted non-commercial use, distribution, and reproduction in any medium, provided the original work is properly cited.

\section{ABSTRACT}

Co-infection by specific Chlamydia species and Human Papilloma Virus has been associated with genital carcinogenesis. Additionally, modern serum biomarkers and risk algorithms for diagnosis and prognosis have proven their efficacy in patients with ovarian cancer although data on endometrial or cervical malignancies are still sparse. We aim to present an unusual case of serum cancer biomarkers increase in a premenopausal female suffering from recurrent uterine bleeding and genital infection by several pathogens. We further discuss proper utilization of these diagnostic tools in such unusual cases.

Keywords: Abnormal uterine bleeding, HPV infection, Cancer biomarkers, Human epididymitis protein 4

\section{INTRODUCTION}

Chlamydia species have been identified as the most important cause for acute pelvic inflammatory disease in females. The WHO estimates that 92 million new cases of chlamydia infections occur worldwide every year. ${ }^{1}$ In the genital system, such an infection can cause cervicitis, endometritis or salpingitis although up to $80 \%$ of these infections are asymptomatic. ${ }^{1}$ Recently, genital coinfection of chlamydia trachomatis and human papilloma virus (HPV) has been associated with genital carcinogenesis as well. ${ }^{2}$

Our aim is to report an unusual case of chlamydial and HPV genital co-infection in a female patient that presented with recurrent uterine bleeding and increased serum risk markers for ovarian malignancy. Furthermore, we will discuss proper utilization of these cancer biomarkers in such atypical benign cases.

Informed consent was obtained from all individual participants included in the study.

\section{CASE REPORT}

A 40 years old (premenopausal) Caucasian female with a free medical history presented suffering from recurrent uterine bleeding without other specific symptoms. After initial physical examination that was unremarkable, the patient underwent a full blood testing that included a blood count $(\mathrm{WBC}=5,300 / \mu \mathrm{L} ; \mathrm{RBC}=4.73 \times 106 \mu \mathrm{L}$; $\mathrm{HCT}=28 \% ; \mathrm{HGB}=8.4 \mathrm{~g} / \mathrm{dl} ; \mathrm{PLT}=301,000 / \mu \mathrm{L}), \mathrm{a}$ biochemical analysis $(\mathrm{Glu}=106 \mathrm{mg} / \mathrm{dl}$; Urea $=33 \mathrm{mg} / \mathrm{dl}$; Crea $=0.8 \mathrm{mg} / \mathrm{dl} ;$ SGOT $=23 \mathrm{mg} / \mathrm{dl}$. SGPT $=25 \mathrm{mg} / \mathrm{dl}$, $\mathrm{CRP}=0.1 \mathrm{mg} / \mathrm{l}$ ) and cancer markers measurement (CEA $=2.41 \mathrm{ng} / \mathrm{ml} ;$ CA $19-9=11.54 \mathrm{U} / \mathrm{ml} ; \mathrm{Ca} 15-3=23.5$ $\mathrm{U} / \mathrm{ml}$; Ca $125=131.4 \mathrm{U} / \mathrm{ml} ; \mathrm{aFP}=1.9 \mathrm{ng} / \mathrm{ml})$. Human epididymidis protein-4 (HE-4) was measured in serum $(\mathrm{He}-4=77 \mathrm{pmol} / \mathrm{L})$ and Risk for Ovarian Malignancy Algorithm (ROMA) score was calculated as well (ROMA $=20.3 \%)^{3}$

Both CA-125 and He-4 were measured by fully automated ARCHITECT instrument (Abbott Diagnostics, ARCHITECT, Abbott Park, IL, USA). Cut-off values 
were set at $35 \mathrm{U} / \mathrm{ml}$ for CA 125 (pre- and postmenopausal females combined), while for $\mathrm{He} 4$ at $150 \mathrm{pmol} / \mathrm{L}$. ${ }^{4}$ The ROMA cut-off values for high-risk patients have been defined as $>7.4 \%$ in premenopausal and $>25.3 \%$ in postmenopausal females. ${ }^{3}$

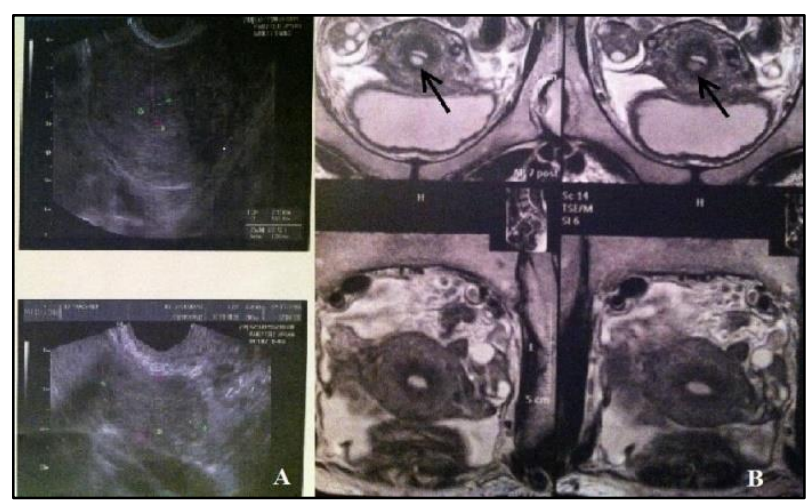

Figure 1: (A) Ultrasound imaging showing thickening of the uterine wall. (B) A magnetic resonance image

(T1 sequence) showing a focal lesion of increased

signal in the anterior lower corpus uteri (arrows).

Vaginal swabs were collected and cultured while an endocervical swab specimen was examined for the presence of chlamydia trachomatis using COBAS ${ }^{\circledR}$ TaqMan® CT Test (Version 2.0, Roche Inc.) and for Neisseria gonorrhoeae using COBAS ${ }^{\circledR}$ AMPLICOR NG Test (Roche Inc.). The patient was positive for Chlamydia trachomatis infection, and negative for Neisseria testing. Cervical fluid was examined and was positive for gardnerella vaginalis, mycoplasma hominis and ureaplasma urealyticum as well. Additionally, papanikolaou (PAP) test showed no malignant cells. From the latter specimen, an HPV DNA typing was performed using linear array HPV Genotyping Test ${ }^{\circledR}$ (Roche Inc). HPV testing was positive for high-risk HPV types 18 and 31, and for low-risk HPV types 62 and 83 .

An ultrasound evaluation of the abdomen showed thickening of the uterine wall [Figure 1(A)]. Therefore, a magnetic resolution imaging (MRI) examination followed that confirmed the ultrasound findings, and showed also a focal lesion of increased signal (T1 sequence) in the anterior lower corpus uteri, possibly a small fibromyoma [Figure 1(B)]. A diagnostic loop biopsy of the cervical wall identified low-grade SIL lesions (HPV infection).

The patient received per os Vibramycin and Azithromycin for 14 days, as well as local Clindamycin cream. After treatment, the patient reported recession of symptoms. Post-treatment serum levels of Ca-125 and $\mathrm{He}-4$, as well as ROMA score, were within normal range $(\mathrm{Ca}-125=14 \mathrm{U} / \mathrm{ml} ; \mathrm{He}-4=39.9 \mathrm{pmol} / \mathrm{L} ; \mathrm{ROMA}=$ $4.47 \%$ ). Patient remains asymptomatic after one year of follow-up.
A written consent was signed by the patient. The case report was in compliance with the Helsinki declaration.

\section{DISCUSSION}

Our patient presented with recurrent uterine bleeding and increased thickening of the uterine wall. The laboratory investigation revealed increased $\mathrm{Ca}-125$ levels and increased ROMA score, indicating a possible malignancy, although HE-4 value was under normal limits. However, a genital infection by several pathogens was identified that was managed successfully with antibiotic therapy, leading to normalization of all cancer markers.

Our patient showed high Ca-125 levels at the beginning, possibly due to the chlamydial infection. This marker has been proved to be a useful tool in ovarian cancer screening and prognosis, especially in postmenopausal females, although it occasionally shows a high falsepositive rate. ${ }^{5,6}$ There are many studies correlating increased $\mathrm{Ca}-125$ levels in serum with benign conditions such as infections or inflammatory diseases. ${ }^{7}$ However, Ca-125 has been proved to be a useful serum tumour marker for monitoring response to chemotherapy, detecting disease recurrence, distinguishing malignant from benign pelvic masses, and potentially improving clinical trial design. ${ }^{8}$ Concerning endometrial cancer, studies have shown that elevated Ca-125 above $30 \mathrm{U} / \mathrm{ml}$ in patients with apparent early-stage disease is a risk factor for the presence of extra-uterine disease and may assist in the management of clinical Stage I endometrial cancer. ${ }^{9}$ Moreover, Ca-125 has been identified as a potential prognostic marker for cervical cancer as well. ${ }^{10}$ However, measurement of $\mathrm{Ca}-125$ as a screening tool in endometrial and cervical cancer has not been proved.

Serum HE-4 levels in our patient were lower than the reference limit, concurring with several studies that show that this marker has a higher sensitivity and specificity for the diagnosis of malignancy compared to Ca-125. ${ }^{8-11}$ Zheng et al have concluded that HE-4 is a more powerful tool than Ca-125 assay to discriminate ovarian cancer from ovarian endometriosis and pelvic inflammatory disease. ${ }^{12}$ However, there are many studies underlining that the combination of both HE-4 and Ca-125 yields a much better diagnostic and prognostic value than each marker alone. ${ }^{13}$ Additionally, HE-4 has been proved more sensitive even in early staged endometrial cancer compared to $\mathrm{Ca}-125$. Zanotti et al showed that HE-4 is more sensitive and specific than $\mathrm{Ca}-125$ in distinguishing endometrial cancer patients from females with normal endometrium, regardless of tumour stage and grade, concurring with our case. ${ }^{14}$

Additionally, ROMA score in our patient showed a high possibility for malignancy, although final diagnosis did not confirm this prediction. The ROMA score has been proved to be a very useful stratification tool in patients with pelvic masses. ${ }^{3}$ Different cut-off values have been 
defined for pre- and postmenopausal females. In a recent meta-analysis, HE-4 yielded a higher specificity compared to Ca-125 and ROMA score, separately or combined, especially in premenopausal patients. ${ }^{5}$ In a recent review, the positive predictive value of ROMA score was reported to be only $34 \%$ for premenopausal females. ${ }^{8}$ However, the algorithm should apply only on selected patients with suspicious pelvic masses to increase its diagnostic accuracy.

Finally, the latest American guidelines regarding ovarian cancer diagnosis underline that U.S. preventive services task force recommends against screening for ovarian cancer in asymptomatic females using ultrasonographic evaluation or $\mathrm{Ca}-125$ measurement (D recommendation). ${ }^{15}$ Only in patients with symptoms or a pelvic mass, serum markers could be useful for differential diagnosis. However, concerning the evaluation of a possible endometrial or cervical cancer, serum markers have not been incorporated in screening strategies or national guidelines, although recent data highlight their potential usefulness in diagnosis and prognosis.

In conclusion, genital cancer risk markers can be elevated in serum even in benign cases of uterine bleeding or infection of the genitalia, risking further unnecessary diagnostic testing or therapy. Therefore, these markers should be properly utilized only in indicated cases, in order to ameliorate false diagnosis. Further studies are needed to estimate the clinical specificity of such risk markers among patients with malignancies and patients affected by different pathogens.

\section{Funding: No funding sources}

Conflict of interest: None declared

Ethical approval: All procedures performed in studies involving human participants were in accordance with the ethical standards of the institutional and/or national research committee and with the 1964 Helsinki declaration and its later amendments or comparable ethical standards

\section{REFERENCES}

1. Taylor BD, Haggerty CL. Management of Chlamydia trachomatis genital tract infection: screening and treatment challenges. Infect Drug Resist. 2011;4:19-29.

2. Bellaminutti S, Seraceni S, De Seta F, Gheit T, Tommasino M, Comar M. HPV and Chlamydia trachomatis co-detection in young asymptomatic women from high incidence area for cervical cancer. J Med Virol. 2014;86(11):1920-5.

3. Bandiera E, Romani C, Specchia C, Zanotti L, Galli $\mathrm{C}$, Ruggeri G, et al. Serum human epididymis protein
4 and risk for ovarian malignancy algorithm as new diagnostic and prognostic tools for epithelial ovarian cancer management. Cancer Epidemiol Biomarkers Prev. 2011;20:2496-506.

4. Molina R, Escudero JM, Augé JM, Filella X, Foj L, Torné A, et al. HE4 a novel tumour marker for ovarian cancer: comparison with CA 125 and ROMA algorithm in patients with gynaecological diseases. Tumour Biol. 2011;32:1087-95.

5. Wang J, Gao J, Yao H, Wu Z, Wang M, Qi J. Diagnostic accuracy of serum HE4, CA125 and ROMA in patients with ovarian cancer: a metaanalysis. Tumour Biol. 2014;35:6127-38.

6. Reade CJ, Riva JJ, Busse JW, Goldsmith CH, Elit L. Risks and benefits of screening asymptomatic women for ovarian cancer: a systematic review and meta-analysis. Gynecol Oncol. 2013;130:674-81.

7. Asher V, Hammond R, Duncan TJ. Pelvic mass associated with raised CA 125 for benign condition: a case report. World J Surg Oncol. 2010;8:28.

8. Jordan SM, Bristow RE. Ovarian cancer biomarkers as diagnostic triage tests. Cur Biom Findings. 2013;3:35-42.

9. Nicklin J, Janda M, Gebski V, Jobling T, Land R, Manolitsas T, et al. LACE trial investigators, the utility of serum CA-125 in predicting extra-uterine disease in apparent early-stage endometrial cancer. Int J Cancer. 2012;131:885-90.

10. Porika M, Vemunoori AK, Tippani R, Mohammad A, Bollam SR, Abbagani S. Squamous cell carcinoma antigen and cancer antigen 125 in southern Indian cervical cancer patients. Asian Pac J Cancer Prev. 2010;11:1745-7.

11. Moore RG, Miller MC, Steinhoff MM, Skates SJ, Lu KH, Lambert-Messerlian G, et al. Serum HE4 levels are less frequently elevated than CA125 in women with benign gynecologic disorders. Am J Obstet Gynecol. 2012;206(4):351e1-8.

12. Zheng H, Gao Y. Serum HE4 as a useful biomarker in discriminating ovarian cancer from benign pelvic disease. Int J Gynecol Cancer. 2012;22:1000-5.

13. Steffensen KD, Waldstrøm M, Brandslund I, Petzold $\mathrm{M}$, Jakobsen $\mathrm{A}$. The prognostic and predictive value of combined HE4 and CA-125 in ovarian cancer patients. Int J Gynecol Cancer. 2012;22:1474-82.

14. Zanotti L, Bignotti E, Calza S, Bandiera E, Ruggeri $\mathrm{G}$, Galli C, et al. Human epididymis protein 4 as a serum marker for diagnosis of endometrial carcinoma and prediction of clinical outcome. Clin Chem Lab Med. 2012;50:2189-98.

15. Moyer VA. Screening for ovarian cancer: U.S. Preventive Services Task Force reaffirmation recommendation statement. Ann Intern Med. 2012;157(12):900-4.

Cite this article as: Sianou A, Galyfos G, Moragianni D, Demeridou S, Kaparos G, Kouskouni E. False increase of serum cancer risk markers in a case of benign uterine bleeding ancy. Int J Reprod Contracept Obstet Gynecol 2016;5:2457-9. 